\title{
Inhibition of the growth of human melanoma cells by methionine enkephalin
}

\author{
DONG-MEI WANG ${ }^{1}$, GUANG-CHUAN WANG ${ }^{2}$, JING YANG $^{3}$, NICOLAS P. PLOTNIKOFF ${ }^{4}$, \\ NOREEN GRIFFIN ${ }^{4}$, YU-MAN HAN ${ }^{1}$, RUI-QUN QI ${ }^{5}$, XING-HUA GAO $^{5}$ and FENG-PING SHAN ${ }^{1}$ \\ ${ }^{1}$ Department of Immunology, School of Basic Medical Science, China Medical University, Shenyang, Liaoning 110122; \\ Departments of ${ }^{2}$ Immunology and ${ }^{3}$ Pathology, School of Basic Medical Science, Liaoning Medical University, \\ Jinzhou, Liaoning 121000, P.R. China; ${ }^{4}$ Immune Therapeutics, Inc., Orlando, FL 32801, USA; \\ ${ }^{5}$ Department of Dermatology, No. 1 Hospital, China Medical University, Shenyang, Liaoning 110001, P.R. China
}

Received October 16, 2015; Accepted August 30, 2016

DOI: $10.3892 / \mathrm{mmr} .2016 .5941$

\begin{abstract}
Melanoma is an aggressive cancer, the incidence of which is increasing worldwide. Limited therapies are currently available, particularly following metastasis. The aim of the present study was to investigate the inhibiting effect of methionine enkephalin (MENK) on human melanoma via opioid receptors. The results of the present study revealed that MENK markedly regulates the proliferation of A375 cells, causing cell cycle arrest in G0/G1 phase and a decrease in the percentage of cells in S and G2/M phases. Reverse transcription-quantitative polymerase chain reaction demonstrated that MENK treatment increased opioid receptor expression in A375 cells. Furthermore, the expression level of survivin, an inhibitory apoptotic protein, was $1.1 \%$ of the level in the control group in the MENK group following $48 \mathrm{~h}$ of treatment. In conclusion, the results of the present study revealed, to the best of our knowledge for the first time, that MENK may inhibit growth and induce apoptosis of A375 cells, and describes a potential mechanism underlying these effects. Therefore, MENK should be investigated as a
\end{abstract}

Correspondence to: Professor Feng-Ping Shan, Department of Immunology, School of Basic Medical Science, China Medical University, 77 Puhe Road, Shenyang North New Area, Shenyang, Liaoning 110122, P.R. China

E-mail: fpshan@mail.cmu.edu.cn

Professor Xing-Hua Gao, Department of Dermatology, No. 1 Hospital, China Medical University, 92 North Second Road, Heping, Shenyang, Liaoning 110001, P.R. China

E-mail: gaobarry@hotmail.com

Abbreviations: MENK, methionine enkephalin; MOR, $\mu$-opioid receptors; DOR, $\delta$-opioid receptors; KOR, $\kappa$-opioid receptors; RT-qPCR, reverse transcription-quantitative polymerase chain reaction; MTS, 5-(3-carboxymethoxyphenyl)2-(4,5-dimethylthiazoly)-3-(4-sulfophenyl) tetrazolium

Key words: methionine encephalin, melanoma, opioid receptors, apoptosis, survivin primary therapy for human melanoma cancer and as an adjuvant to other chemotherapies. Further studies are required to develop an optimal strategy for the use of MENK for the treatment of human cancers.

\section{Introduction}

Human melanoma is the most malignant skin cancer (1) and its incidence has risen rapidly in recent years. It is the most common skin cancer in females aged 25-29 (2). The median survival for patients with metastatic melanoma is $\sim 7$ months $(3,4)$; surgery is currently the primary treatment. Drug resistance is a common problem associated with anticancer drugs $(5,6)$. Natural products and medicines have been developed as cosmeceutical ingredients to treat esthetic skin problems, including skin darkening and wrinkles (7-10). Therefore, it may be beneficial to develop natural therapeutic agents for the treatment of melanoma.

Methionine enkephalin (MENK), an endogenous opioid neuropentapeptide composed of Tyr-Ala-Ala-Phe-Met, is derived from pre-enkephalin and circulates in the blood at low concentrations. Various types of opioid receptors have been described and two of the most studied are $\mu$ (MOR) and $\delta$ (DOR) $(11,12)$. These receptors are expressed on the surface of immune cells and various tumor cells, including pancreatic cancer and melanoma cells $(13,14)$. MENK upregulates the activity of immune cells and may inhibit tumor growth $(15,16)$. MENK and opioid receptors form a biological axis that regulates cell proliferation by delaying G1/S cell cycle progression under homeostatic conditions and in neoplasia, and inhibits pancreatic tumor progression (17). However, the molecular mechanism underlying this effect remains unclear. The present study aimed to investigate the mechanism underlying the therapeutic effect of MENK on melanoma, to determine whether MENK may be a potential therapeutic strategy for the treatment of cancer and other conditions in which the immune system is suppressed.

\section{Materials and methods}

Cell culture. A375 human melanoma cells were provided by No. 1 Hospital, China Medical University (Shenyang, China), and cultured in RPMI 1640 (Gibco; Thermo Fisher Scientific, 
Inc., Waltham, MA, USA), supplemented with $10 \%$ fetal calf serum (FCS; Biological Industries, Kibbutz Beit Haemek, Israel), $100 \mathrm{U} / \mathrm{ml}$ penicillin and $100 \mu \mathrm{g} / \mathrm{ml}$ streptomycin. Cells were cultured at $37^{\circ} \mathrm{C}$ and $5 \% \mathrm{CO}_{2}$, and cells in the exponential phase of growth were used for subsequent experiments.

Reagents. MENK ( $\geq 97 \%$ purity) was provided by Penta Biotech, Inc. (Union City, CA, USA). Reverse transcription-quantitative polymerase chain reaction (RT-qPCR) kits were purchased from Takara Bio, Inc. (Otsu, Japan). TRIzol ${ }^{\circledR}$ was obtained from Invitrogen; Thermo Fisher Scientific, Inc. Propidium iodide (PI), dimethylsulfoxide and thymidine were purchased from Sigma-Aldrich; Merck Millipore (Darmstadt, Germany).

Cell culture and MENK administration in vitro. A375 cells were treated with various concentrations of $\operatorname{MENK}(0,2.5$, 5, 10 and $12.5 \mathrm{mg} / \mathrm{ml}$ in RPMI 1640) for various times (24, 48, 72 and 96 h). Cell viability was evaluated by MTS assays and flow cytometry.

Morphologic observation of A375 cells. Cells were treated with $12.5 \mathrm{mg} / \mathrm{ml}$ MENK for $48 \mathrm{~h}$ and alterations in morphology were observed under a conventional light microscope.

Cell growth and cell cycle analysis. A375 cells were collected as target cells and seeded into 96 -well plates $\left(3 \times 10^{3} /\right.$ well). The A375 proliferation in each well was determined $3 \mathrm{~h}$ following plating by measuring the optical density at $570 \mathrm{~nm}$ using a bichromatic microplate reader.

A375 cells were seeded in 6-well plates for $48 \mathrm{~h}$ (5x10 $/$ well). The cells were trypsinized, washed with phosphate-buffered saline (PBS) and fixed in $70 \%$ ethanol. Prior to flow cytometric analysis, fixed cells were stained with $0.5 \mathrm{mg} / \mathrm{ml}$ PI in PBS containing $50 \mathrm{mg} / \mathrm{ml}$ RNase A. Cells were acquired on a flow cytometer and the data was analyzed using ModiFit LT $^{\mathrm{TM}}$ software version 4.0 (BD Biosciences, Franklin Lakes, NJ, USA).

RT-qPCR analysis of MENK-associated opioid receptors. The mRNA expression levels of MOR, DOR and $\kappa$-opioid receptors (KOR) were detected by RT-qPCR. A375 cells (3x10\% $/$ well) were divided into 3 groups: MENK $(12.5 \mathrm{mg} / \mathrm{ml})$, MENK with naltrexone (NTX; $1 \mathrm{mg} / \mathrm{ml}$; Penta Biotech, Inc., Union City, CA, USA) and control. Cells were cultured for 48 h. Total RNA was extracted from cells of the 3 groups using TRIzol, and cDNA was synthesized using reverse transcriptase. Aliquots of cDNA were used as the template for qPCR reactions containing primers for MOR, DOR, KOR or $\beta$-actin. The primers were synthesized by Invitrogen; Thermo Fisher Scientific, Inc. and had the following oligo-nucleotide sequences: Forward, 5'-TGCTCCTGGCTCAACTTG TCC-3' and reverse, 5'-GCGTGCTAGTGGCTAAGGCAT CTG-3' for MOR; forward, 5'-CCATCCACATCTTCGTCA TCGTCTG-3' and reverse, 5'-TCGTCCAGGAAGGCGTAG AGAAC-3' for DOR; forward, 5'-TCTCCCAGTGCTTGC CTTCTCC-3' and reverse, 5'-TTGCGGTCTTCATCTTCG TGTATCG-3' for KOR; and forward, 5'-TTCCAGCGTTCC TTCTTGGGTAT-3' and reverse, 5'-GTTGGCATAGAG
Table I. Methionine encephalin inhibits A375 cell invasion.

\begin{tabular}{lcc}
\hline Group & Cell numbers & P-value \\
\hline Control & $80.67 \pm 7.73$ & \\
$2.5 \mathrm{mg} / \mathrm{ml}$ & $79.33 \pm 8.21$ & \\
$5 \mathrm{mg} / \mathrm{ml}$ & $72.17 \pm 5.65$ & $\mathrm{P}=0.26$ \\
$10 \mathrm{mg} / \mathrm{ml}$ & $64.67 \pm 5.01$ & $\mathrm{P}<0.001$ \\
$12.5 \mathrm{mg} / \mathrm{ml}$ & $57.83 \pm 3.31$ & $\mathrm{P}<0.001$ \\
\hline
\end{tabular}

GTGTTTACGG-3' for $\beta$-actin. The $\mathrm{qPCR}$ reactions were performed using an Applied Biosystems 7500 Real-Time PCR System (Thermo Fisher Scientific, Inc.) and SYBR ${ }^{\circledR}$ Premix EX Taq II. The cycling conditions were as follows: An initial denaturation step at $95^{\circ} \mathrm{C}$ for $2 \mathrm{~min}$, followed by 40 cycles of denaturation at $95^{\circ} \mathrm{C}$ for $15 \mathrm{sec}$ and annealing at $60^{\circ} \mathrm{C}$ for $1 \mathrm{~min}$. Data were normalized to $\beta$-actin using the $2^{-\Delta \Delta \mathrm{Cq}}$ method (18).

Apoptosis analysis. Apoptosis was assessed by labeling A375 cells with Annexin V-fluorescein isothiocyanate (FITC) and PI (BD Biosciences) according to the manufacturer's protocol. The samples were acquired on a FACSCalibur flow cytometer (BD Biosciences) and analyzed with ModiFit LT software version 4.0 or WinMDI version 2.9 (The Scripps Research Institute, La Jolla, CA, USA).

Apoptosis antibodyassay. A375 cells $\left(1 \times 10^{7}\right)$ were seeded into plates and the assay was performed using a RayBio ${ }^{\circledR}$ Human Apoptosis Antibody array (RayBiotech, Inc., Norcross, GA, USA) according to the manufacturer's protocol. Signals were imaged using an Axon Genepix ${ }^{\circledR}$ microarray scanner (Molecular Devices, LLC, Sunnyvale, CA, USA).

Transwell invasion assay. The invasive ability of cells was determined by transwell assay. Briefly, the $8-\mu \mathrm{m}$ pore polycarbonate filters were coated with extracellular matrix (50 $\mu \mathrm{g}$ /filter; Sigma-Aldrich; Merck Millipore); $500 \mu \mathrm{l}$ $\left(2 \times 10^{5}\right)$ cells were added to the upper chamber and $500 \mu 1$ RPMI 1640 with $10 \%$ FCS was pipetted into the lower chamber. The non-invasive cells in the upper chamber were gently wiped off $12 \mathrm{~h}$ later. The cells that penetrated to the lower chamber were stained with crystal violet, imaged and counted. Each experiment was performed in triplicate.

Statistical analysis. All experiments were performed in triplicate at least. Data are expressed as the mean \pm standard deviation. Statistical analyses were performed SPSS software version 13.0 (SPSS, Inc., Chicago, IL, USA). Groups were compared using one-way analyses of variance followed by the Student-Newman-Keuls post hoc test. $\mathrm{P}<0.05$ was considered to indicate a statistically significant difference.

\section{Results}

Morphological alterations in A375 cells. Following culture with $12.5 \mathrm{mg} / \mathrm{ml} \mathrm{MENK}$ for $48 \mathrm{~h}$ the A375 cells exhibited typical apoptotic morphology with long protrusions and 
A

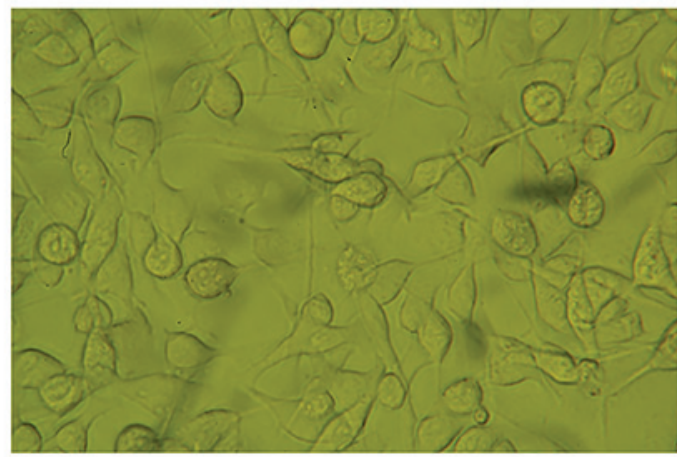

B

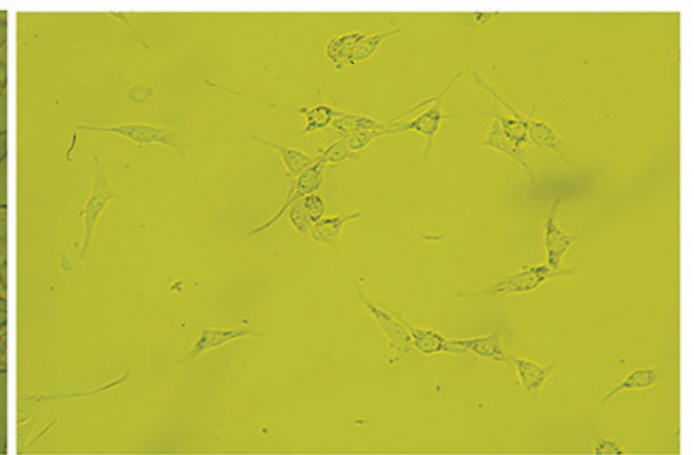

Figure 1. Morphology of A375 cells. (A) A375 cells cultured in RMPI 1640 only. (B) A375 cells treated with 12.5 mg/ml MENK for 48 h. Following MENK treatment, cells exhibited oval or irregularly shaped nuclei, with long protrusions and a reduction in cell number. Magnification, x200. MENK, methionine encephalin.

extensions. A375 cells exhibited disintegration and apoptotic bodies as presented in Fig. 1.

MENK inhibits A375 cell proliferation. The viability of A375 cells treated with MENK was reduced in a dose- and time-dependent manner. At $12.5 \mathrm{mg} / \mathrm{ml} \mathrm{MENK}$, the rate of cell growth inhibition reached a plateau; the rate of inhibition was 57.64 and $63.8 \%$ at 72 and $96 \mathrm{~h}$, respectively, compared with the control group ( $\mathrm{P}<0.001$; Fig. 2A).

MENK induces cell cycle arrest. The effect of MENK on cell cycle distribution was analyzed by flow cytometry (Fig. 2B). The percentage of the $10 \mathrm{mg} / \mathrm{ml} \mathrm{MENK}$ group in $\mathrm{G} 0 / \mathrm{G} 1$ phase was $69.41 \%$ compared with $57.14 \%$ of the control cells $(\mathrm{P}=0.015)$. Correspondingly, the number of $10 \mathrm{mg} / \mathrm{ml}$ MENK group cells in S phase decreased to $14.8 \%$ compared to $29.52 \%$ of control cells $(\mathrm{P}=0.004)$. The percentage of cells subjected to $10 \mathrm{mg} / \mathrm{ml}$ MENK treatment in G2/M phase was $15.79 \%$ compared with $13.34 \%$ of control cells $(\mathrm{P}=0.24$; Fig. 2C).

MENK increases mRNA expression levels of opioid receptors on A375 cells. Following treatment with $12.5 \mathrm{mg} / \mathrm{ml}$ MENK, mRNA expression levels of MOR, DOR and KOR on A375 cells were determined by RT-qPCR (Fig. 3). mRNA expression levels of DOR, MOR and KOR were 6.68, 5.46 and 2.81, respectively, compared with 1 in the control group. These differences reached significance for DOR $(\mathrm{P}<0.001)$ and MOR ( $\mathrm{P}=0.001)$. This increased expression of all 3 ORs was attenuated by NTX $(\mathrm{P}=0.004)$.

MENK induces apoptosis in vitro. Following MENK treatment of A375 cells, decreased viability was accompanied by alterations in cell morphology, including the appearance of blebs and cell disintegration into apoptotic bodies. This was confirmed by annexin V/PI staining; there was a significant dose-dependent increase in annexin $\mathrm{V}^{+} / \mathrm{PI}$ apoptotic cells following MENK treatment, compared with control cells (Fig. 4). Apoptosis appeared to peak at $48 \mathrm{~h}$. The rate of apoptosis increased from $4.22 \%$ in the control group to $25.1 \%$ in the $12.5 \mathrm{mg} / \mathrm{ml}$ MENK treatment group $(\mathrm{P}=0.001)$.
Assay of human apoptosis mediators. Various factors have been described to be responsible for the induction of apoptosis. The expression of 47 genes was analyzed in A375 cells following 12, 24 or $48 \mathrm{~h}$ exposure to 0 or $12.5 \mathrm{mg} / \mathrm{ml}$ MENK (Fig. 5A and B). Analysis revealed that the expression of apoptosis inducer proteins was elevated and apoptosis inhibitor proteins declined in MENK-treated cells compared with controls. The expression of survivin and X-linked inhibitor of apoptosis (XIAP) was 1.1 and $3.4 \%$, respectively, in the MENK group compared with control at $48 \mathrm{~h}(\mathrm{P}<0.001$; Fig. 5C).

MENK inhibits cell invasion. The invasion capacity of A375 cells was determined using a transwell assay. The number of cells that invaded through the membrane decreased significantly by $10.5 \%$ in the $5 \mathrm{mg} / \mathrm{ml}$ MENK group $(\mathrm{P}=0.026)$ and $28.3 \%$ in $12.5 \mathrm{mg} / \mathrm{ml} \mathrm{MENK}$ group $(\mathrm{P}<0.001)$ compared with the control group (Table I).

\section{Discussion}

MENK, an endogenous neuropeptide, may contribute to immune responses against tumors and viral infections by activating multiple types of immune cells, enabling them to secrete various cytokines or directly kill target cells $(19,20)$. Previous studies have provided evidence for the direct modulation of the immune system via opioid receptors $(21,22)$. Investigations into MENK have revealed that the nuclear membrane of certain cancer cells expressed receptors to which MENK bound, resulting in marked growth inhibition of cancer cells in vitro $(23-28)$.

The present study investigated the detailed mechanisms underlying the effects of MENK on human melanoma A375 cell growth. The results of the present study revealed that the concentration of MENK that achieved optimal inhibition of A375 cell growth, of those assessed, was $12.5 \mathrm{mg} / \mathrm{ml}$. In addition, the mRNA expression levels of DOR, MOR and KOR in A375 cells increased following MENK treatment; DOR and MOR were predominant. This increased expression was attenuated by NTX. Furthermore, MENK induced apoptosis of A375 cells and inhibited invasion.

The inhibitory effects of MENK on cell replication were first described in developing rat brain (29) and in tissue culture 

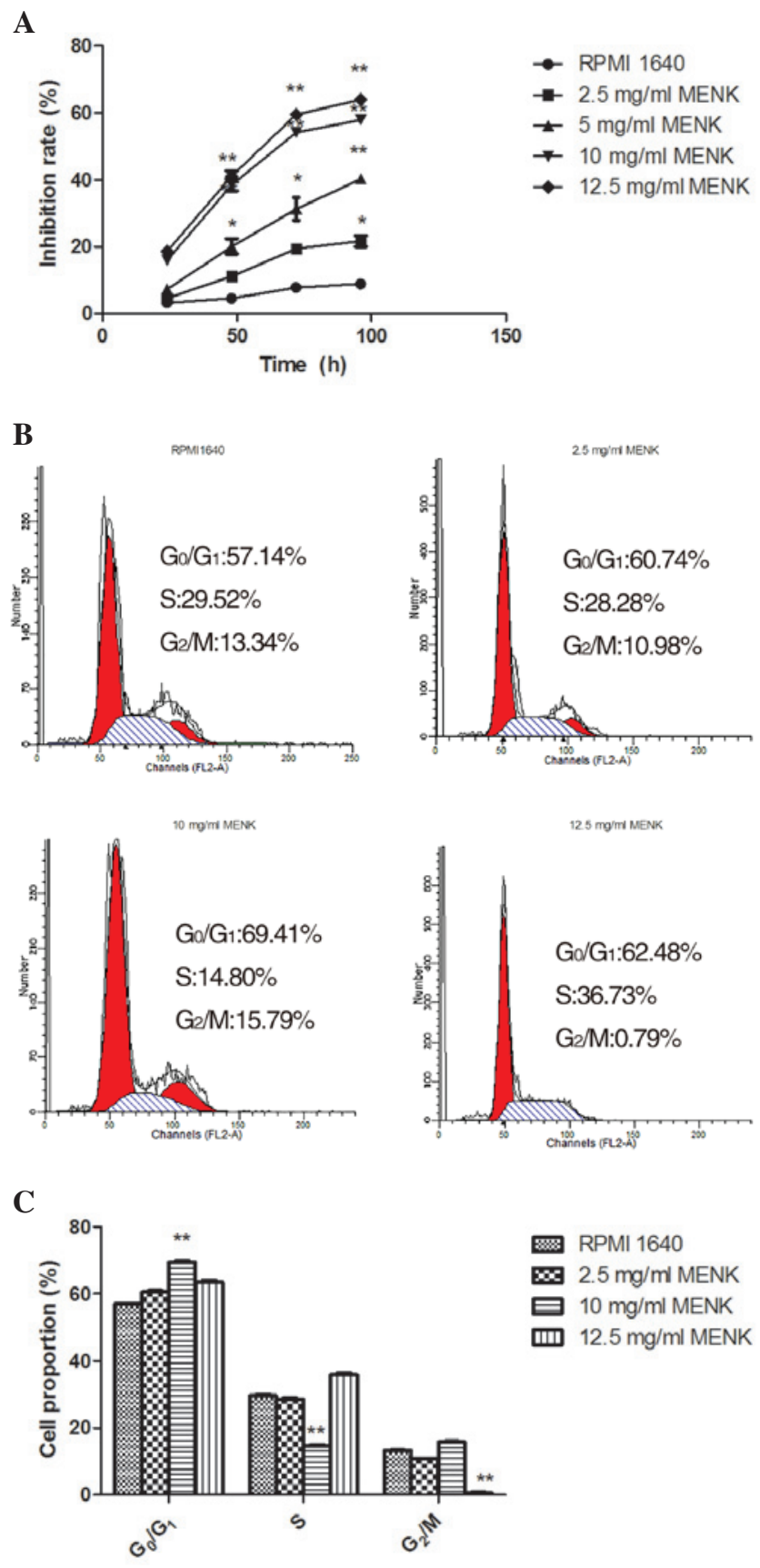

Figure 2. MENK inhibits A375 growth by cell cycle arrest. (A) The inhibition rate of A375 cells treated with $0,2.5,5,10$ or $12.5 \mathrm{mg} / \mathrm{ml}$ MENK for $24,48,72$ and $96 \mathrm{~h}$ was evaluated by an MTS assay. The inhibition rate in the $12.5 \mathrm{mg} / \mathrm{ml}$ MENK group was significantly increased compared with control cultures receiving RPMI 1640. ${ }^{*} \mathrm{P}<0.05$ and ${ }^{* *} \mathrm{P}<0.01$ vs. RPMI 1640. (B) The cell cycle of A375 cells treated with $0,2.5,10$ or $12.5 \mathrm{mg} / \mathrm{ml}$ MENK for $48 \mathrm{~h}$ was analyzed by flow cytometry. (C) The percentage of $10 \mathrm{mg} / \mathrm{ml}$ MENK-treated cells in G0/G1 was significantly elevated compared with control. ${ }^{* *} \mathrm{P}<0.01$ vs. RPMI 1640 . Mean percentage of cells in G0/G1, S, and G2/M phases are presented. MENK, methionine encephalin.

studies on mouse and human neuroblastoma (30). MENK inhibits DNA synthesis and replication of healthy cells and tissues (31), human neoplasia and bacteria. The activity of MENK is receptor-mediated, dose- and time-dependent, and reversible. This neuropeptide is present in developing and regenerating tissues, and has been identified in embryonic

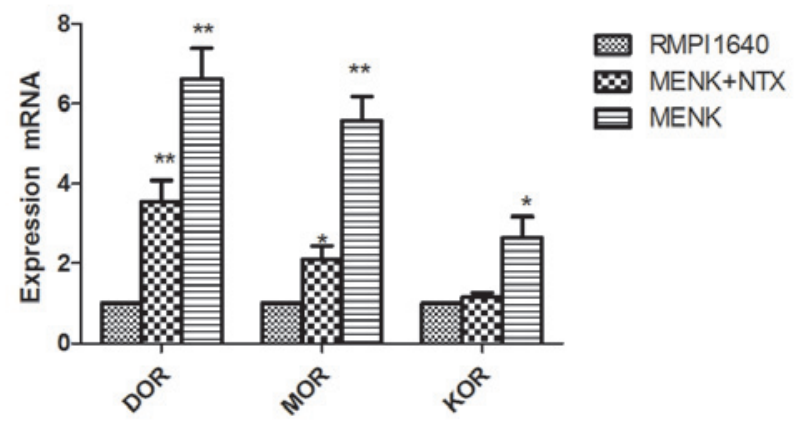

Figure 3. mRNA expression levels of DOR, MOR and KOR in A375 cells. mRNA expression levels were detected using reverse transcription-quantitative polymerase chain reaction following treatment with RPMI 1640 only, MENK or MENK + NTX in vitro for $48 \mathrm{~h} . \beta$-actin served as an internal reference. MENK upregulated the mRNA expression levels of DOR, MOR and KOR in A375 cells. DOR and MOR were significantly upregulated following MENK treatment compared with the RPMI 1640 group. The increased expression was attenuated by NTX. " $\mathrm{P}<0.05$ and ${ }^{* *} \mathrm{P}<0.01$ vs. RPMI 1640 DOR, $\delta$-opioid receptors; MOR, $\mu$-opioid receptors; KOR, $\kappa$-opioid receptors; MENK, methionine encephalin; NTX, naltrexone.

tissues and numerous human cancers (32). Exogenous MENK inhibited progression and growth of a tumor overexpressing opioid receptors (33).

The present study demonstrated that MENK inhibited proliferation and induced apoptosis in A375 human melanoma cells for, to the best of our knowledge, the first time. Cells exhibited growth inhibition following exposure to MENK and MENK arrested cell cycle progression in G0-G1 phase. The action of MENK may therefore be closely associated with another key regulator of the G1-S phase transition, the tumor suppressor retinoblastoma protein. The effect of MENK on the cell cycle may be associated with opioid receptors; this is consistent with the study by Zagon et al (17), indicating the specific and singular receptor for MENK action on the replication of a human pancreatic cancer cell line is MOR.

MENK significantly increased apoptosis in A375 cells; XIAP and survivin were differentially expressed between control and MENK-treated groups. XIAP and survivin are members of the inhibitor of apoptosis (IAP) family, which are the most powerful apoptosis inhibitors currently identified. Survivin is important for the regulation of cell mitosis and apoptosis and is a dual-function protein, affecting the mitotic apparatus assembly and cytokinesis time, and regulating apoptosis through phosphorylation. Survivin is a mediator of apoptosis resistance and cell cycle progression, and is highly expressed in cancer. A previous study have revealed that survivin is upregulated in melanoma compared with healthy melanocytes, and is required for melanoma cell viability (34). A previous study in melanoma cell lines and animal models have implicated survivin as an important molecule in melanoma pathogenesis (35). Its clinical relevance in this disease is underscored by studies demonstrating a correlation between survivin expression and poor outcome in patients $(36,37)$. The role of p53 in tumor suppression has been well characterized, acting in a gene-specific manner as a transcriptional activator (for pro-apoptotic genes including bax) or repressor (for various oncogenes including c-myc) (38). Induction of wild type $\mathrm{p} 53$ by DNA-damaging agents, including UV light and doxorubicin, 
A

RMPI 1640

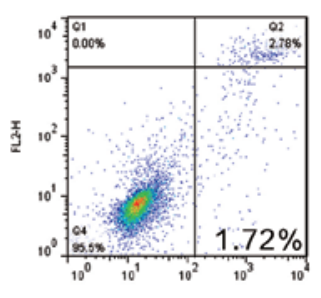

FL. 1 H

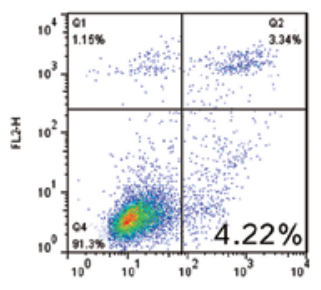

ค1..

$48 \mathrm{~h}$

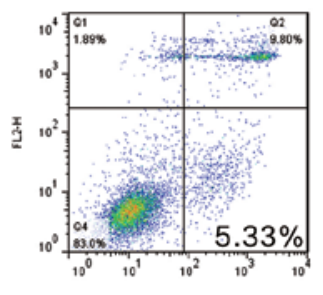

FL1.H

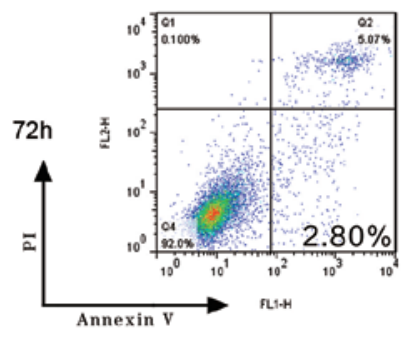

$2.5 \mathrm{mg} / \mathrm{ml}$ MENK

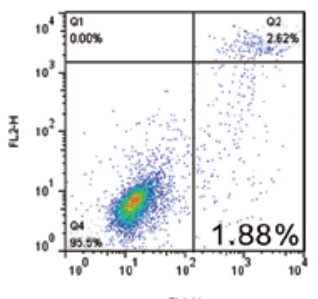

FL. 1 H
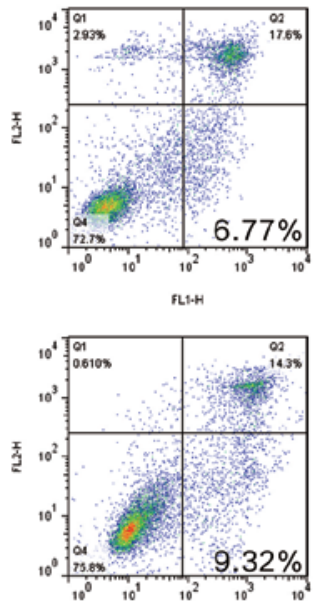

sL1.

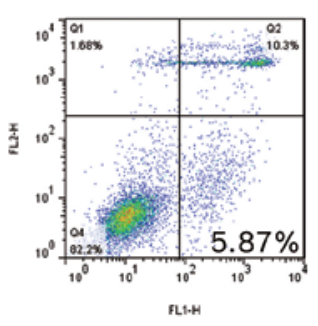

$10 \mathrm{mg} / \mathrm{ml}$ MENK

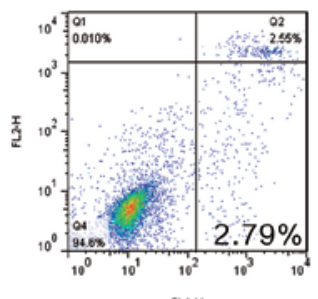

FLᄂ. H
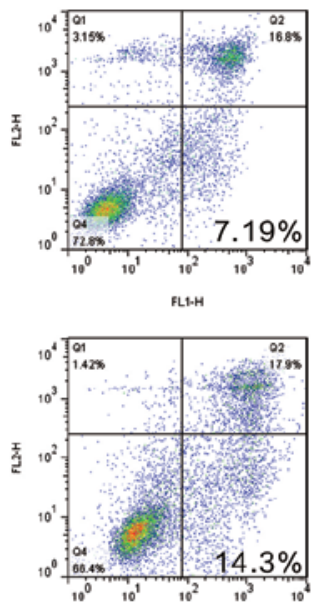

Fเ:-H

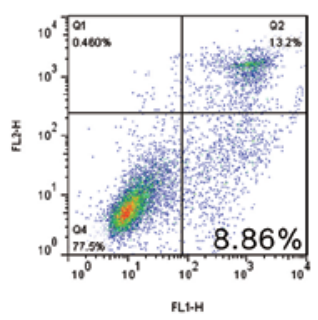

$12.5 \mathrm{mg} / \mathrm{ml}$ MENK

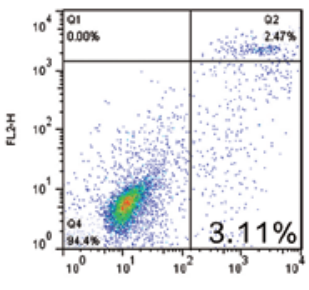

FL1.H

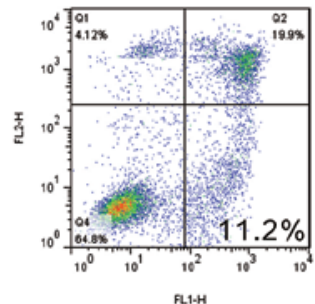

FLth

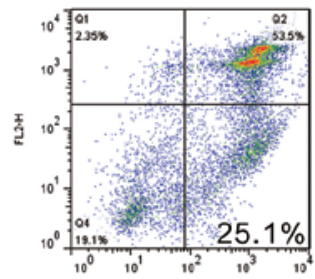

FL1-H

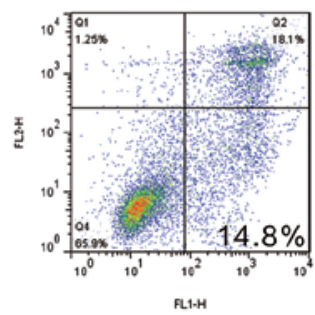

B

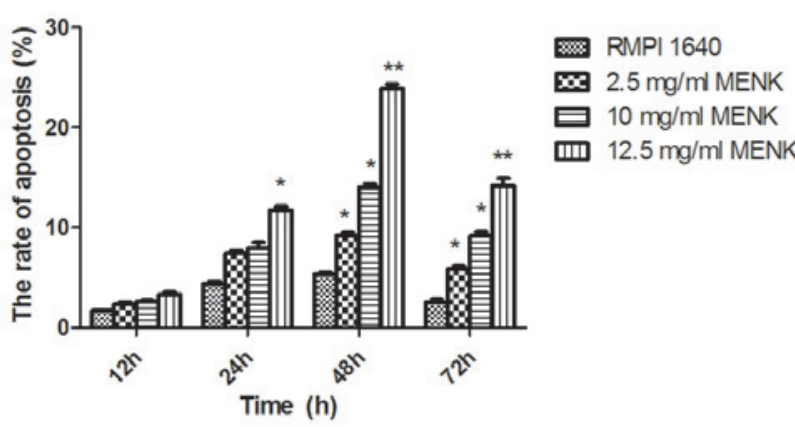

Figure 4. MENK induces apoptosis in A375 cells. (A) Annexin V/PI staining of A375 cells was performed following treatment with 0, $2.5,5,10$ or 12.5 mg/ml MENK for 12, 24, 48 or $72 \mathrm{~h}$. Apoptotic cells were defined as annexin $\mathrm{V}^{+} / \mathrm{PI}^{-}$. Experiments were performed 3 times with similar results and one representative experiment is presented. (B) The rate of apoptosis increased from $4.22 \%$ in the control group to $25.1 \%$ in the $12.5 \mathrm{mg} / \mathrm{ml} \mathrm{MENK}$ treatment group. ${ }^{*} \mathrm{P}<0.05$ and ${ }^{* *} \mathrm{P}<0.01$ vs. RPMI 1640. MENK, methionine encephalin; PI, propidium iodide.

or introduction of exogenous p53 (39), downregulated survivin expression in malignant cells. In the present study, the expression of survivin was 0.011-fold in the MENK group compared with the control group at $48 \mathrm{~h}$, suggesting that MENK may induce apoptosis by inhibiting survivin expression.

In conclusion, the results of the present study revealed, to the best of our knowledge for the first time, that MENK may inhibit growth and induce apoptosis of A375 cells, and describes a potential mechanism underlying these effects. MENK is readily degraded, without alteration of cell migration, differentiation or survival and thus may be considered a biotherapeutic agent. Clinically, MENK is safe, non-toxic and extends survival and reduces tumor burden in patients with unresectable pancreatic cancer (40). Therefore, MENK should be investigated as a primary therapy for human melanoma cancer and as an adjuvant to other chemotherapies. Further studies are required to develop 
A

\begin{tabular}{|c|c|c|c|c|c|c|c|c|c|c|c|c|c|}
\hline & $A$ & $B$ & 8 & $D$ & $E$ & $F$ & $G$ & $\mathrm{H}$ & 1 & J & $\mathrm{K}$ & 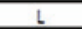 & $\bar{M}$ \\
\hline 7 & Pos 1 & Pes 2 & Pos 3 & $\mathrm{Neg}$ & Neg & 6030 & bax & 60.2 & $\mathrm{bec}_{\mathrm{w}}$ & 810 & BIM & Cascasse & $\cos 025 s 8$ \\
\hline 2 & Pos1 & $P_{055} 2$ & Pos 3 & $\mathrm{Neg}$ & $\mathrm{Neg}$ & 628 & $b 2 x$ & $b 012$ & $b 0 \mathrm{dz}$ & BID & BIM & Cascases & caspasese \\
\hline 3 & $C D \perp 0$ & CD4OL & ClaP.2 & $\operatorname{croc}$ & DP6 & Fas & FasL & $n e q$ & $\mathrm{HS} \cdot 27$ & HSP6O & HSP70 & HTPA & $\mid 1 G F=1$ \\
\hline 7 & $C D 40$ & CD40L & CIAP.2 & 9000 & DPG & Fas & FasL & neg & HSP27 & HSPQO & HSP7O & HTPA & $\mid G F=1$ \\
\hline$\frac{3}{3}$ & $\mid G F \cdot \|$ & $16 F 8.1$ & IGFBP.2 & $16=8 P .3$ & $16 F 8 \times .4$ & $16 F 39.5$ & $16 F 8 P .6$ & $16 F .159$ & $\operatorname{lin}$ & 021 & 027 & 0.53 & SMAC \\
\hline 6 & $\mid G F=\|$ & $19 F 6 \mathrm{~B} \cdot 1$ & 1G:BP.2 & IGFBP.3 & $1678 \times \cdot 4$ & 16F30.5 & $16,69.6$ & 16F:15R & Imin & 921 & 027 & .053 & SMAC \\
\hline 7 & Survivin & ${ }_{S} \mathrm{STN}_{\mathrm{N} 1}$ & STNE=A2 & TNFalacha & TNFFrotata & TRALP:1 & TRAILR:2 & TPALR:3 & TRALRA-4 & XIAP & Neg & $N_{q_{9}}$ & $\mathrm{Ne}_{3}$ \\
\hline 9 & Survivin & STNE.R1 & TNF.92 & NNF.20ha & TNF-beta & AIL & PAILC & TPAILR:3 & TRALIRA-4 & $\overline{X I A P}$ & & & \\
\hline
\end{tabular}

B
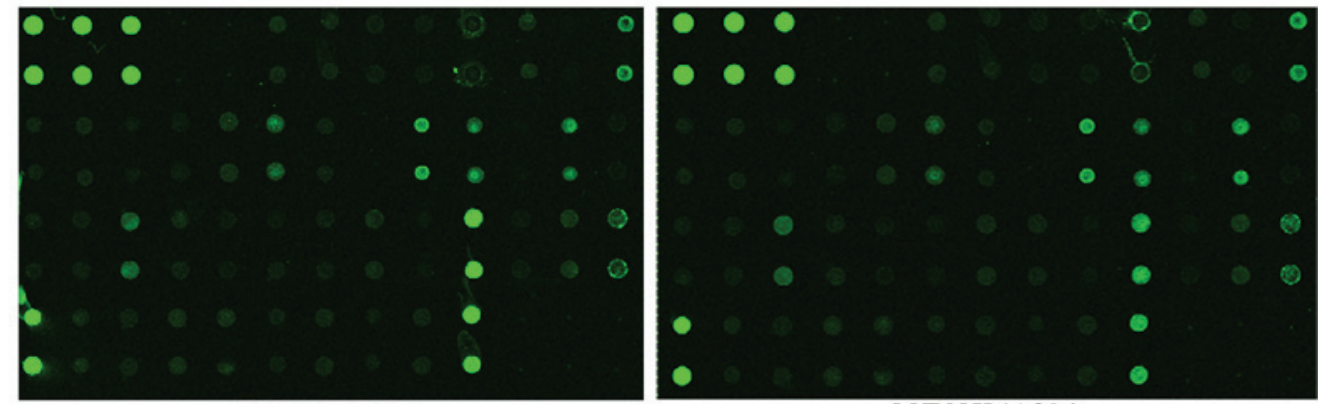

RPMI 1640

$\operatorname{MENK}(12 \mathrm{~h})$

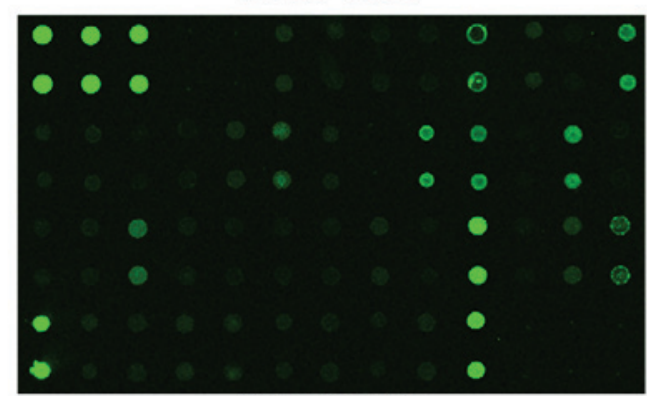

MENK(24h)

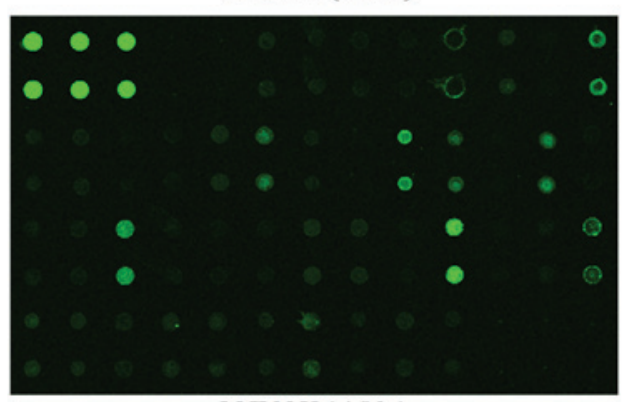

$\operatorname{MENK}(48 \mathrm{~h})$

C

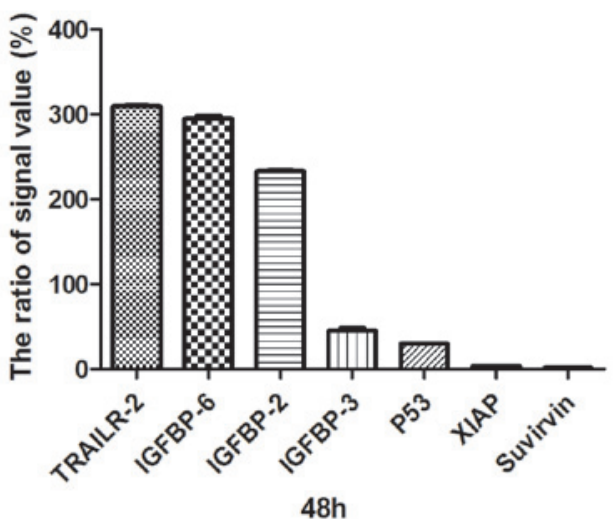

Figure 5. Apoptotic protein analysis. Analysis of 43 apoptotic factors in A375 cells was performed following treatment with $12.5 \mathrm{mg} / \mathrm{ml} \mathrm{MENK}$ for 12,24 or $48 \mathrm{~h}$. (A) The position of each apoptotic factor. (B) Proteins bound to antibody spots in the MENK treatment and control groups. (C) Quantification of the data at $48 \mathrm{~h}$. The rate of signal value between MENK and control groups. MENK, methionine encephalin; TRAILR-2, tumor necrosis factor-related apoptosis-inducing ligand receptor 2; IGFBP, insulin-like growth factor-binding protein; XIAP, X-linked inhibitor of apoptosis.

an optimal strategy for the use of MENK in the treatment of human cancers.

\section{Acknowledgements}

The present study was supported by the China Liaoning Province Supporting Construction of Discipline Platforms in Universities and the China Liaoning Science Foundation (grant nos. 2009225008-7 and 2012225016). The authors thank other colleagues who contributed to the present study.

\section{References}

1. Miller AJ and Mihm MC Jr: Melanoma. N Engl J Med 355: 51-65, 2006. 
2. Linos E, Swetter SM, Cockburn MG, Colditz GA and Clarke CA Increasing burden of melanoma in the United States. J Invest Dermatol 129: 1666-1674,2009.

3. Howlader N, Noone AM, Krapcho M, Neyman N, Aminou R, Waldron W, Altekruse SF, Kosary CL, Ruhl J, Tatalovich Z, et al (eds): SEER Cancer Statistics Review, 1975-2009 (Vintage 2009 Populations). http://seer.cancer.gov/csr/1975_2009_pops09/ accessed on October, 312013

4. Bedikian AY, Millward M, Pehamberger H, Conry R, Gore M, Trefzer U, Pavlick AC, DeConti R, Hersh EM, Hersey P, et al: Bcl-2 antisense (oblimersen sodium) plus dacarbazine in patients with advanced melanoma: The Oblimersen Melanoma Study Group. J Clin Oncol: 24, 4738-4345, 2006.

5. Engelman JA and Jänne PA: Mechanisms of acquired resistance to epidermal growth factor receptor tyrosine kinase inhibitors in non-small cell lung cancer. Clin Cancer Res 14: 2895-2899, 2008.

6. Pao W, Miller VA, Politi KA, Riely GJ, Somwar R, Zakowski MF, Kris MG and Varmus H: Acquired resistance of lung adenocarcinomas to gefitinib or erlotinib is associated with a second mutation in the EGFR kinase domain. PLoS Med 2: e73, 2005.

7. Hunt KJ, Hung SK and Ernst E: Botanical extracts as anti-aging preparations for the skin: A systematic review. Drugs Aging 27: 973-985, 2010.

8. Antignac E, Nohynek GJ, Re T, Clouzeau J and Toutain H: Safety of botanical ingredients in personal care products/cosmetics. Food Chem Toxicol 49: 324-341, 2011.

9. Reuter J, Merfort I and Schempp CM: Botanicals in dermatology: An evidence-based review. Am J Clin Dermatol 11: 247-267, 2010.

10. Baumann L, Woolery-Lloyd H and Friedman A: 'Natural' ingredients in cosmetic dermatology. J Drugs Dermatol 8: (Suppl 6) s5-s9, 2009.

11. Donahue RN, McLaughlin PJ and Zagon IS: Cell proliferation of human ovarian cancer is regulated by the opioid growth factor-opioid growth factor receptor axis. Am J Physiol Regul Integr Comp Physiol 296: R1716-R1725, 2009.

12. Vujic V, Stanojević S and Dimitrijević M: Methionine-enkephalin stimulates hydrogen peroxide and nitric oxide production in rat peritoneal macrophages: Interaction of mu, delta and kappa opioid receptors. Neuroimmunomodulation 11: 392-403, 2004

13. Avella DM, Kimchi ET, Donahue RN, Tagaram HR, McLaughlin PJ,Zagon IS and Staveley-O'Carroll KF: The opioid growth factor-opioid growth factor receptor axis regulates cell proliferation of human hepatocellular cancer. Am J Physiol Regul Integr Comp Physiol 298: R459-R466, 2010.

14. Zagon IS, Verderame MF and McLaughlin PJ: The biology of the opioid growth factor receptor (OGFr). Brain Res Brain Res Rev 38: 351-76, 2002.

15. Zagon IS and McLaughlin PJ: Targeting opioidergic pathways as a novel biological treatment for advanced pancreatic cancer. Expert Rev Gastroenterol Hepatol 6: 133-135, 2012.

16. Gredicak M, Supek F, Kralj M, Majer Z, Hollosi M, Smuc T, Mlinarić-Majerski K and Horvat S: Computational structure-activity study directs synthesis of novel antitumor enkephalin analogs. Amino Acids 38: 1185-1191, 2010.

17. Zagon IS, Roesener CD, Verderame MF, Ohlsson-Wilhelm BM, Levin RJ and McLaughlin PJ: Opioid growth factor regulates the cell cycle of human neoplasias. Int J Oncol 17: 1053-1061, 2000.

18. Livak KJ and Schmittgen TD: Analysis of relative gene expression data using real-time quantitative PCR and the 2(-Delta Delta C(T)) Method. Methods 25: 402-408, 2001.

19. DeBenedette MA, Calderhead DM, Ketteringham H, Gamble AH, Horvatinovich JM, Tcherepanova IY, Nicolette CA and Healey DG: Priming of a novel subset of CD28+ rapidly expanding high-avidity effector memory CTL by post maturation electroporation-CD40L dendritic cells is IL-12 dependent. J Immunol 181: 5296-5305, 2008.

20. Johnson AJ, Mendez-Fernandez Y, Moyer AM, Sloma CR, Pirko I, Block MS, Rodriguez M and Pease LR: Antigen-specific CD $8^{+} \mathrm{T}$ cells mediate a peptide-induced fatal syndrome. J Immunol 174: 6854-6862, 2005.

21. Carr DJ and Carpenter GW: Morphine-induced suppression of cytotoxic $\mathrm{T}$ lymphocyte activity in alloimmunized mice is not mediated through a naltrindole-sensitive delta opioid receptor. Neuroimmunomodulation 2: 44-53, 1995.
22. Carr DJ,Carpenter GW,Garza HH Jr,BakerML and GebhardtBM: Cellular mechanisms involved in morphine-mediated suppression of CTL activity. Adv Exp Med Biol 373: 131-139, 1995.

23. Zagon IS, Verderame MF, Hankins $\mathrm{J}$ and McLaughlin PJ: Overexpression of the opioid growth factor receptor poten-tiates growth inhibition in human pancreatic cancer cells. Int J Oncol 30: 775-83, 2007.

24. Zagon IS, Donahue RN and McLaughlin PJ: Opioid growth factor-opioid growth factor receptor axis is a physiological determinant of cell proliferation in diverse human cancers. Am J Physiol Regul Integr Comp Physiol 297: 1154-1161, 2009.

25. Zagon IS, Kreiner S, Heslop JJ, Conway AB, Morgan CR and McLaughlin PJ: Prevention and delay in progression of human pancreatic cancer by stable overexpression of the opioid growth factor receptor. Int J Oncol 33: 317-323, 2008.

26. Goldenberg D, Zagon IS, Fedok F, Crist HS and McLaughlin PJ. Expression of opioid growth factor (OGF)-OGF receptor (OGFr)axis in human nonmedullary thyroid cancer. Thyroid 18: $1165-1170,2008$

27. McLaughlin PJ, Kreiner S, Morgan CR and Zagon IS: Prevention and delay in progression of human squamous cell carcinoma of the head and neck in nude mice by stable overexpression of the opioid growth factor receptor. Int J Oncol 33: 751-757, 2008.

28. Smith JP, Bingaman SI, Mauger DT, Harvey HH, Demers LM and Zagon IS: Opioid growth factor improves clinical benefit and survival in patients with advanced pancreatic cancer. Open Access J Clin Trials 2010: 37-48, 2010.

29. Wu Y, McLaughlin PJ and Zagon IS: Ontogeny of the opioid growth factor, [Met5]-enkephalin, preproenkephalin gene expression, and the zeta opioid receptor in the developing and adult aorta of rat. Dev Dyn 211: 327-337, 1998.

30. Zagon IS, Ruth TB and McLaughlin PJ: Nucheocytoplasmic distibution of opioid growth factor and its receptor and its receptor in tongue epithelium. Anat Rec A Discov Mol Cell Evol Biol 282: 24-37, 2005.

31. McLaughlin PJ, Levin RJ and Zagon IS: Regulation of human head and neck squamous cell carcinoma growth in tissue culture by opioid growth factor. Int J Oncol 14: 991-998, 1999.

32. Zagon IS, Porterfield NK and McLaughlin PJ: Opioid growth factor-opioid growth factor receptor axis inhibits proliferation of triple negative breast cancer. Exp Biol Med (Maywood) 238: 589-599, 2013.

33. Tsanova A, Jordanova A, Dzimbova T, Pajpanova T, Golovinsky E and Lalchev Z: Interaction of methionine-enkephalins with raft-forming lipids: Monolayers and BAM experiments. Amino Acids 46: 1159-1168, 2014.

34. Liu T, Brouha B and Grossman D: Rapid induction of mitochondrial events and caspase-independent apoptosis in Survivin-targeted melanonma cells. Oncogene 23: 39-48, 2004.

35. Yang J, Wahdan-Alaswad R and Danielpour D: Critical role of Smad2 in tumor suppression and transforming growth factor-beta-induced apoptosis of prostate epithelial cells. Cancer Res 69: 2185-2190, 2009.

36. Song K, Krebs TL and Danielpour D: Novel permissive role of epidermal growth factor in transforming growth factor beta (TGF-beta) signaling and growth suppression. Mediation by stabilization of TGF-beta receptor type II. J Biol Chem 281: 7765-7774, 2006.

37. Shehata HH, Abou Ghalia AH, Elsayed EK, Ziko OO and Mohamed SS: Detection of Survivin protein in aqueous humor and serum of retinoblastoma patients and its clinical significance. Clin Biochem 43: 362-366, 2010.

38. Tang L, Ling X, Liu W, Das GM and Li F: Transcriptional inhibition of p21WAF1/CIP1 gene (CDKN1) expression by survivin is at least partially p53-dependent: Evidence for survivin acting as a transcription factor or co-factor. Biochem Biophys Res Commun 421: 249-254, 2012.

39. Song K, Cornelius SC and Danielpour D: Development and characterization of DP-153, a nontumorigenic prostatic cell line that undergoes malignant transformation by expression of dominant-negative transforming growth factor beta receptor type II. Cancer Res 63: 4358-4367, 2003.

40. Zagon IS and McLaughlin PJ: Opioid growth factor and the treatment of human pancreatic cancer: A review. World J Gastroenterol 20: 2218-2223, 2014 